\section{FORAGE RESOURCES OF LATIN AMERICA}

$\mathrm{B}$ ULLETIN 37 of the Imperial Bureau of Pasture and Forage Crops, Aberystwyth, has been prepared by Hugo W. Alberts, in association with the Technical Collaboration Branch, Office of Foreign Agricultural Relations, United States Department of Agriculture. It has been issued by the Imperial Agricultural Bureaux (Pp. 24. 2s. 6d.).

Grazing and browsing, as it is best known to the forester, of domestic or semi-domestic animals has become an increasingly intensified problem in the modern world. The present monograph gives information in some detail on the position in Peru and their forage resources. The author divides the country roughly into three geographic regions, the coastal region, the sierra and the oriente or montana. The latter, situated to the east of the Andes, consists mainly of tropical forest, the grazing and pasture question having little importance. Since remote times, the Andean Indians of Peru have grazed llamas and alpacas, native to the grasslands of the sierra. These animals had been domesticated and raised for their meat and hides by the time the Spaniards arrived. The llamas were used also as pack animals. On account of the nature of the grasses in many of the mountain valleys, there was always some grazing even in the driest times, because there were two general types of forage, consisting of short grasses, fairly high in palatability, and tall grasses, of lower food value. The tall grasses were not eaten during the rainy season when there was plenty of the short grass available, and consequently the former formed a reserve for the winter months and periods of drought.

Along the coast, forage is produced chiefly to feed dairy cattle. In the sierra, native range grasses supply forage for sheep, llamas, alpacas and some beef and dairy animals. The kinds of forage grown along the coast are principally alfalfa and para grass, supplemented by maize, which is cut and fed in the green state. The native range lands of the sierra produce various species of grasses, which may be classified into two general groups, namely, tall grasses and short grasses, already alluded to. Tropical rain forest species of grasses comprise the principal forage in the oriente.

Some of the pasture lands in different regions are irrigated. The number of animals which can be grazed on areas of from two to three hectares varies considerably, and probably requires a further close study.

\section{EARTHQUAKES DURING JULY-AUGUST, 1947}

$\mathrm{T}$ WELVE large earthquakes and a score of smaller ones were recorded by the world's seismographs during July, and nine large shocks with numerous smaller ones during August. Provisional epicentres for the large earthquakes have been determined by the U.S. Coast and Geodetic Survey in co-operation with Science Service and the Jesuit Seismological Association.

The largest earthquakes of the two-monthly period were those of July 29 and August 5. That of July 29 occurred on the borders of Tibet and Burma, and was recorded in America, New Zealand and Europe. At Kew the resulting ground amplitude reached $290 \mu$ at maximum. The earthquake of August 5 had its epicentre about lat. $25^{\circ} \mathrm{N}$., long. $62^{\circ} \mathrm{E}$. in the Arabian Sea south of Baluchistan. It was registered in America and Europe, where the ground amplitude reached $250 \mu$ at Stuttgart. It is not yet known whether the Tibet earthquake did any serious damage or not.

Deep-focus earthquakes occurred on July 13 east of the Fiji Islands (100 km. deep), on July 25 in the northern Argentine $(400 \mathrm{~km}$. deep) and on September 2 west of the Tonga Islands $(200 \mathrm{~km}$. deep). These demonstrate that the viscosity of the material in the earth was large at these depths, places and times, thus giving a clue to earth structure.

Two unusual epicentres are placed in North America; one on July 10 in Baffin Bay, recorded at American stations and Stuttgart, and the other on August 10 at lat. $41 \cdot 9^{\circ}$ N., long. $84 \cdot 5^{\circ} \mathrm{W}$., in southern Michigan, recorded in North America but not in Europe.

Also during the period movement was going on in mid-Atlantic, where an earthquake occurred at lat. $54^{\circ} \mathrm{S}$., long. $30^{\circ} \mathrm{W}$. near South Georgia on July 23, and one on August 9 at lat. $1^{\circ}$ N., long. $28^{\circ}$ W., the latter known to be a seismic area. On July 15 repeated earthquake shocks brought down the dome of the church of San Felipe at Pasto, Colombia, and destroyed the high altar. Houses also collapsed and serious damage was done to the University and to the airport. Four people were seriously injured, and the tremors may have been associated with the eruption of a volcano near the city. This shock may have been the one which was registered at $\mathrm{De}$ Bilt, Belgrade and Stuttgart near 14h. 30m. G.M.T.

\section{FORTHCOMING EVENTS}

(Meetings marked with an asterisk * are open to the public)

\section{Monday, April 26}

Institution of ELECTRICAL ENGINEERS (at Savoy Place, Victoria Embankment, London, W.C.2), at 5.30 p.m.-Discussion on "Industrial Applications of Photo-electric Cells' (to be opened by Mr. F. Baxendale).

Roxal Geographical Sochtity (at Kensington Gore, London S.W.7), at 5.30 p.m.-Dr. Edward Lynam: "English Surveyors and Mapmakers, 1555-1611".

INSTITUTION OF THE RUBBER INDUSTRY, MANCHESTER SECTION (at the Engineers' Club, Albert Square, Manchester), at 6.15 p.m.Annual General Meeting.

\section{Tuesday, April 27}

BRITISH SOCIETY FOR INTERNATIONAL BIBLIOGRAPHY (at the Institution of Electrical Engineers, Savoy Place, Victoria Embankment, London, W.C.2), at 2.30 p.m.-Papers.

UNIVERSITY COLIEGE, LONDON (in the Physiology Theatre, Gower Street, London, W.C.1), at 5 p.m.-Dr. D. B. Fry : "Speech". (Further lectures on May 4 and 11.)*

Royal Statistioal Socterty (at the London School of Hygiene and Tropical Medicine, Keppel Street, London, W.C.1), at 5.15 p.m.and Tropical Wishart: "The Teaching of 'Statistics".

INSTITUTION OF CIVIL ENaINEERS (at Great George Street, London, S.W.1), at 5.30 p.m.-James Forrest Lecture.

MANCHESTER GEOGRAPHICAL SOCIETY (in the Geographical Hall St. Mary's Parsonage, Manchester), at 6.30 p.m.-Dr. Mary Clarke : "Impressions of a Visit to China".

SOCIETY OF INSTRUMENT TECHNOLOGY (at the Royal Society of Tropical Medicine and Hygiene, Manson House, 26 Portland Place, Tropical Medicine and Hygiene, Manson House, 26 Portland Place, of Modern American instrumentation".

Tuesday, April 27-Friday, April 30

INSTITUTE of WELDING (at Manchester).-Annual Spring Meeting.

Wednesday, April 28

Physical Soctety, Colour Group (at the Royal Photographic Society, 16 Prince's Gate, London, S.W.7), at 3.30 p.m.-Dr. R. K Schofleld: "The Report on Colour Terminology"; Discussion on "The Correlation of Colour Terms used in Physics, Industry and Ordinary Speech". 